\title{
Global Cities and The Future of Demographic Transformation
}

\author{
İskender Güneş ${ }^{1}$ ()
}

\begin{abstract}
The structural transformation adventure of urbanization in global cities is always closely linked to economic development. Today, thanks to the demographic transformation that includes this economic situation, migrants have started to spread to small and medium-sized cities and global cities with less capacity and resources. In this process, the attitude of city administrations can balance the demographic change that occurs and the opportunities and costs that may be created by a wave of immigration. At the same time, it is important for cities to be prepared for possible situations by having future plans in place, to shape the future of both cities and their demographic structure in a positive sense. Although national legislation can regulate cross-border migration, concepts that can reveal the effects of migration on cities are needed. Among these, countries with weaknesses in areas such as city planning, financing and management, land allocation, housing supply, and basic services fall short of controlling migration flow and demographic planning. In addition, population changes that change and shape the demographic structure of cities on a global scale should be handled within this framework. Planning to be made on a global scale and with a holistic perspective will help each city shape its expectations about its future visually.
\end{abstract}

\section{Keywords}

Global, Global City, Demography, Transformation

1 Corresponding author: İskender Güneş (PhD), Marmara University, Faculty of Political Sciences, Department of Local Governments and Urban Policies, Istanbul, Turkey. E-mail: iskender34gunes@gmail.com ORCID: 0000-0003-4829-3220 To cite this article: Gunes, I. (2021). Global Cities and The Future of Demographic Transformation. Journal of Social Policy Conferences, 81, 485-499. https://doi.org/10.26650/jspc.2021.81.950195 


\section{Introduction}

Among the features of the globalization trend in the emergence and shaping of the global cities issue, the internationalization of production and new international business presence come to the fore. The existence of new migration movements from South to North pushes the states towards the phenomenon of internationalization due to the new competition environment (Scholte, 1999, p.15.). In this sense, growth accelerated in the developed cities of Europe and North America in the 19th century. Most of these cities reached prominent positions until the middle of the 20th century. During this period, significant volatility processes were experienced in the global economy. This process has been associated with immigration in the Caribbean, Central America, Korea, the former Soviet Union, the Middle East and Mexico.

The intensive individual and mass migration process that emerged as a product of this period has also caused the population of global cities to undergo transformation transformation (Sennet, 2002, p.329). In this transformation, it is seen that the main difficulty is related to migration from rural areas to cities. It should also be considered that the reasons for migration are also variable. While in some parts of Africa, city spaces are safer than rural areas, where conflicts between regions and ethnicities result in violent civil wars, it is emphasized that in China, India and Latin America the city often offers less economic opportunities than rural areas (Hambleton and Gross, 2007, p.219).

In addition, many people have to leave their countries and "globalization brings a range of pressures to national borders, and they are increasingly permeable to flows of money and ideas. Migration laws have long been a key site of national assertions - of power, of identity, of "nationness"." (Dauvergne, 2008 , p.17). It is seen that each country has a share in this migration process in proportion to its own facts and conditions. (The World Bank).

\section{Migration and the Population Growth Process in the World}

In the light of UN “2017 World Population Forecast Report" data; the general population of the world was 7.6 billion as of 2017. (United Nations, 2017 Revision of World Population Prospects, 2017, p.12.). According to the information that continues to be updated, the world population continues its numerical change with an addition of 83 million every year. The data provided 
by the report predicted that about the global population. The global population is expected to be about 8.4 or 8.7 billion by 2030 . Moreover, it is also expected to reach between 9.4 and 10.2 billion in 2050. The estimate for the year 2100 is stated as 9.6 and 13.2.

As it is stated in the Pew Research Center report named" Total Fertility Rate by Religion, Projected From 2010-2050" examines the impact of the fertility rate in the world on the future population growth; while the fertility rate hovers at around 2.5 in 2010, this rate is expected to decline to 2.1 in 2050 (Pew Research Center, Total Fertility Rate by Religion, Projected From 2010-2050). While there was a high birth rate of 5.0 in 1950 , even if this number decreased to 2.0 , the world population would increase rather than decrease. The world population is expected to increase by 2050 (Pew Research Center, Total Fertility Worldwide, 1950-2050). The World Employment and Social Outlook: Trends 2017 report prepared by the International Labour Organization, has also made a contribution to evaluate the proportion of the working population in terms of demographics, which adds to the demographic structure of the cities. Based on this fact, it would be appropriate to examine the report named World Economic Social Outlook prepared by the ILO. Data presented by this report shows that developing countries have experienced an improvement in terms of both poverty and the poverty of workers. In addition, the report shows that developing countries do not show the same level of improvement in population and employment growth (International Labour Organization, World Employment and Social Outlook: Trends 2017). The Average Life Expectancy at Birth report of the Pew Research Center has a significant impact to understand the population growth of cities, increased from 48 years between $1950-55$ to 69 years in the $2010-2015$ period. It is stated that in the period covering the years 2050-2055, life expectancy may reach 76 years (Pew Research Center, Average Life Expectancy at Birth, 1950-2050, 2015).

Migration flows experienced today cause the inclusion of different ethnic structures in countries. According to the UN High Commissioner for Refugees, there are 17.184.291 Refugees under UNHCR's mandate, 2.729.521 Asylumseekers and 36,627,127 IDPs (internally displaced person) of concern to UNHCR in the world. And for 2020 the number of IDPs of concern to UNHCR became 48.557.439 (UNCHR Statistics The World in Numbers). As of 2019, there are 3,632,622 Total Syrians under temporary protection in Turkey(Göç İdaresi Genel Müdürlüğü). 
Until the early eighties, the population growth of cities as a developing whole has followed a natural increase. It is stated that this population increase constitutes approximately $60 \%$ of the growth. In addition, it is stated that $25 \%$ to $32 \%$ of the demographic fluctuation in cities is due to net migration (Harris, 1990, p.13). In this process, the number of nation states has doubled during 50 years, and today, the number of UN member states has reached 193 in total (UN Member States). At the same time, the number and size of cities which have a population above 100,000 has increased. During this period, the number of cities of this size increased 10 times to over 4000 .

\section{Demographic Future of Cities}

The past and future projections about the urban population of the world between 1980 and 2020 should also be considered at this point, as shown in Table 1. This table, which is the product of the work by Peter Hall, shows the state of the Latin American, Caribbean, Asian and African urban populations for the next quarter century. Accordingly, this population structure, which is expected to increase twice as much, also reveals the shape of the demographic structure. According to the study of Urban Land, Housing, And Transportation: The Global Challenge, these data show that 27 new megacities will be at the center of future urban life. It is estimated that 18 of these cities, which will have a population of over 10 million, will be in Asia (Hall, 2007).

Table 1

World Urban Population (1980-2000-2020)

\begin{tabular}{lcccccc}
\hline & \multicolumn{3}{c}{ Urban Population \% } & \multicolumn{3}{c}{ Urban Population Growth Rate \% } \\
\hline & $\mathbf{1 9 8 0}$ & $\mathbf{2 0 0 0}$ & $\mathbf{2 0 2 0}$ & $\mathbf{1 9 8 0 - 8 5}$ & $\mathbf{2 0 0 0 - 0 5}$ & $\mathbf{2 0 2 0 - 2 5}$ \\
\hline World & 39 & 47 & 57 & 2.6 & 2.2 & 1.7. \\
Africa & 27 & 38 & 49 & 4.4 & 4.0. & 3.0. \\
Europe & 69 & 75 & 80 & 0.8. & 0.3. & 0.1. \\
North America & 74 & 77 & 82 & 1.2. & 1.0. & 0.9. \\
Central America & 60 & 67 & 73 & 3.1. & 2.0 & 1.5. \\
South America & 68 & 80 & 85 & 3.1. & 1.8. & 1.1. \\
Asia & 27 & 38 & 50 & 3.6. & 2.8. & 2.0. \\
Oceania & 71 & 70 & 72 & 1.4. & 1.3. & 1.3. \\
Developing Countries & 29 & 41 & 52 & 3.8. & 2.9. & 2.1. \\
Developed Countries & 71 & 76 & 81 & 0.9. & 0.5. & 0.3. \\
\hline
\end{tabular}

Source: Global Urban Development Magazine (20 December 2020).

The number of megacities with a population of 10 million or more in the world has become 37 (Demographia World Urban Areas 13th Annual Edition, 
2017 , p.4.) With the estimated demographic increase, the number of these cities is expected to increase to 40 by 2050 . In the light of the evaluations, we see the estimation of the urban area population: (UN The World's Cities in 2018, p.6).

The number of urban areas and their population by continents estimated for 2018 is as follows within table 2 ;

Table 2

World Continental Urban Areas Population Estimation for 2018

\begin{tabular}{|c|c|c|c|c|c|}
\hline Africa & Asia & Europe & $\begin{array}{c}\text { Latin America } \\
\text { \&Caribbean }\end{array}$ & $\begin{array}{c}\text { North } \\
\text { America }\end{array}$ & Oceania \\
\hline $\begin{array}{l}3 \text { Cites/ } \\
10 \text { million }\end{array}$ & $\begin{array}{c}20 \text { cities/ } \\
10 \text { million and } \\
\text { more }\end{array}$ & $\begin{array}{l}2 \text { cities of } 10 \\
\text { million }\end{array}$ & $\begin{array}{l}6 \text { cities/ } \\
10 \text { million }\end{array}$ & $\begin{array}{l}2 \text { cities/ } \\
10 \text { million } \\
\text { and more }\end{array}$ & \\
\hline $\begin{array}{l}5 \text { Cities/ } \\
5 \text { or } 10 \\
\text { million }\end{array}$ & $\begin{array}{c}28 \text { cities/ } \\
\text { 5-10 million }\end{array}$ & $\begin{array}{c}4 \text { cities/ } \\
\text { 5-10 million }\end{array}$ & $\begin{array}{c}3 \text { cities/ } \\
\text { 5-10 million }\end{array}$ & $\begin{array}{c}8 \text { cities/ } \\
\text { 5-10 million }\end{array}$ & \\
\hline $\begin{array}{l}55 \text { Cities/ } \\
1 \text { or } 5 \\
\text { million }\end{array}$ & $\begin{array}{l}250 \text { cities/ } \\
1-5 \text { million }\end{array}$ & $\begin{array}{l}52 \text { cities/ } \\
1-5 \text { million }\end{array}$ & $\begin{array}{l}63 \text { cities/ } \\
1-5 \text { million }\end{array}$ & $\begin{array}{l}41 \text { cities/ } \\
1-5 \text { million }\end{array}$ & $\begin{array}{c}6 \text { cities } \\
\text { between } 1-5 \\
\text { million }\end{array}$ \\
\hline $\begin{array}{l}71 \text { Cities/ } \\
500 \text { thousand } \\
\text { and } 1 \text { million }\end{array}$ & $\begin{array}{l}333 \text { cities } \\
500 \text { thousand } \\
\text { and } 1 \text { million }\end{array}$ & $\begin{array}{c}88 \text { cities/ } \\
500 \text { thousand } \\
\text { and } 1 \text { million }\end{array}$ & $\begin{array}{l}57 \text { cities/ } \\
500 \text { thousand } \\
\text { and } 1 \text { million }\end{array}$ & $\begin{array}{c}48 \text { cities/ } \\
500 \text { thousand } \\
\text { and } 1 \text { million }\end{array}$ & $\begin{array}{l}1 \text { city/ } \\
500 \text { thousand } \\
\text { and } 1 \text { million }\end{array}$ \\
\hline
\end{tabular}

Source: UN The World's Cities in 2018, Population distribution by size class of settlement and region, 2018 and 2030 (10 September 2020), p.6

As table 2 shows that in 2018 the number of cities in the world with 10 million and more population estimated are 33, and cities with 5 or 10 million population are 48 . In the same time, the number of cities in the world with 1 or 5 million population estimated are 461, and cities with 500 thousand or 1 million population are estimated as 598 .

And the number of urban areas and their population by continents for 2030 predicted as follows within table 3; 
Table 3

World Continental Urban Areas Population Prediction for 2030

\begin{tabular}{|c|c|c|c|c|c|}
\hline Africa & Asia & Europe & $\begin{array}{c}\text { Latin America \& } \\
\text { Caribbean }\end{array}$ & $\begin{array}{c}\text { North } \\
\text { America }\end{array}$ & Oceania \\
\hline $\begin{array}{l}5 \text { cities/ } \\
10 \text { million } \\
\text { and above }\end{array}$ & $\begin{array}{c}27 \text { cities/ } \\
10 \text { million and } \\
\text { above }\end{array}$ & $\begin{array}{l}3 \text { cities/ } \\
10 \text { million } \\
\text { and above }\end{array}$ & $\begin{array}{c}6 \text { cities/ } \\
10 \text { million and } \\
\text { above }\end{array}$ & $\begin{array}{c}2 \text { cities/ } \\
10 \text { million and } \\
\text { above }\end{array}$ & \\
\hline $\begin{array}{l}13 \text { cities/ } \\
5 \text { or } 10 \\
\text { million }\end{array}$ & $\begin{array}{c}34 \text { cities/ } \\
5-10 \text { million }\end{array}$ & $\begin{array}{c}3 \text { cities/ } \\
5-10 \text { million }\end{array}$ & $\begin{array}{c}5 \text { cities/ } \\
5-10 \text { million }\end{array}$ & $\begin{array}{c}9 \text { cities/ } \\
\text { 5-10 million, }\end{array}$ & $\begin{array}{c}2 \text { cities } \\
\text { between } \\
5-10 \text { million }\end{array}$ \\
\hline $\begin{array}{l}81 \text { cities/ } \\
1 \text { or } 5 \\
\text { million }\end{array}$ & $\begin{array}{l}330 \text { cities/ } \\
1-5 \text { million }\end{array}$ & $\begin{array}{l}55 \text { cities/ } \\
1-5 \text { million }\end{array}$ & $\begin{array}{l}77 \text { cities/ } \\
1-5 \text { million }\end{array}$ & $\begin{array}{l}50 \text { cities } \\
1-5 \text { million }\end{array}$ & $\begin{array}{l}4 \text { cities/ } \\
1-5 \text { million }\end{array}$ \\
\hline $\begin{array}{l}111 \text { cities/ } \\
500 \text { thousand } \\
\text { and } 1 \\
\text { million. }\end{array}$ & $\begin{array}{l}387 \text { cities/ } \\
500 \text { thousand } \\
\text { and } 1 \text { million }\end{array}$ & $\begin{array}{c}94 \text { cities/ } \\
500 \text { thousand } \\
\text { and } 1 \text { million }\end{array}$ & $\begin{array}{c}60 \text { cities/ } \\
500 \text { thousand and } 1 \\
\text { million }\end{array}$ & $\begin{array}{l}55 \text { cities/ } \\
500 \text { thousand } \\
\text { and } 1 \text { million. }\end{array}$ & $\begin{array}{l}3 \text { cities/ } \\
500 \\
\text { thousand } \\
\text { and } 1 \\
\text { million. }\end{array}$ \\
\hline
\end{tabular}

Source: UN The World's Cities in 2018, Population distribution by size class of settlement and region, 2018 and 2030, (10 September 2020), p.6

As table 3 shows that it is predicted for 2030 the number of cities in the world with 10 million and more population is predicted to be 43 , and cities with 5 or 10 million population are 66 . The number of cities in the world with 1 or 5 million population predicted to be 597 , and cities with 500 thousand or 1 million population are predicted as 710. In addition, the UN "Urban Agglomerations" study reveals the total population of cities in the world, country populations, urban and rural populations and differences between them (United Nations Department of Economic and Social Affairs Population Division, 2014, p.1). The World City Survey conducted by the UN deals with the 1950, 1990, 2015 and 2030 forecast of cities (United Nations, World Urbanization Prospects The 2014 Revision, 2015, p.21.).

\section{The Role of Migration in Transforming Cities}

Global cities also contain demographic characteristics of their own. Global cities, which lead the way in many aspects of urbanization in the world, are attractive for their developed urban infrastructure and services. At the beginning of this process, it is seen that in the 2nd half of the 19th century, almost all Western cities started to undergo a transformation. In the middle of the 19th century, countries including France, Germany, the USA and Britain had a rural population structure, while in the next century they had an urban society. This 
process is also called the age of urban revolution between 1848 and 1945(Sennet, 2002, p.286.). The demographic structure of global cities differs in terms of both diversity and density in the following years. (See Figure 1.)

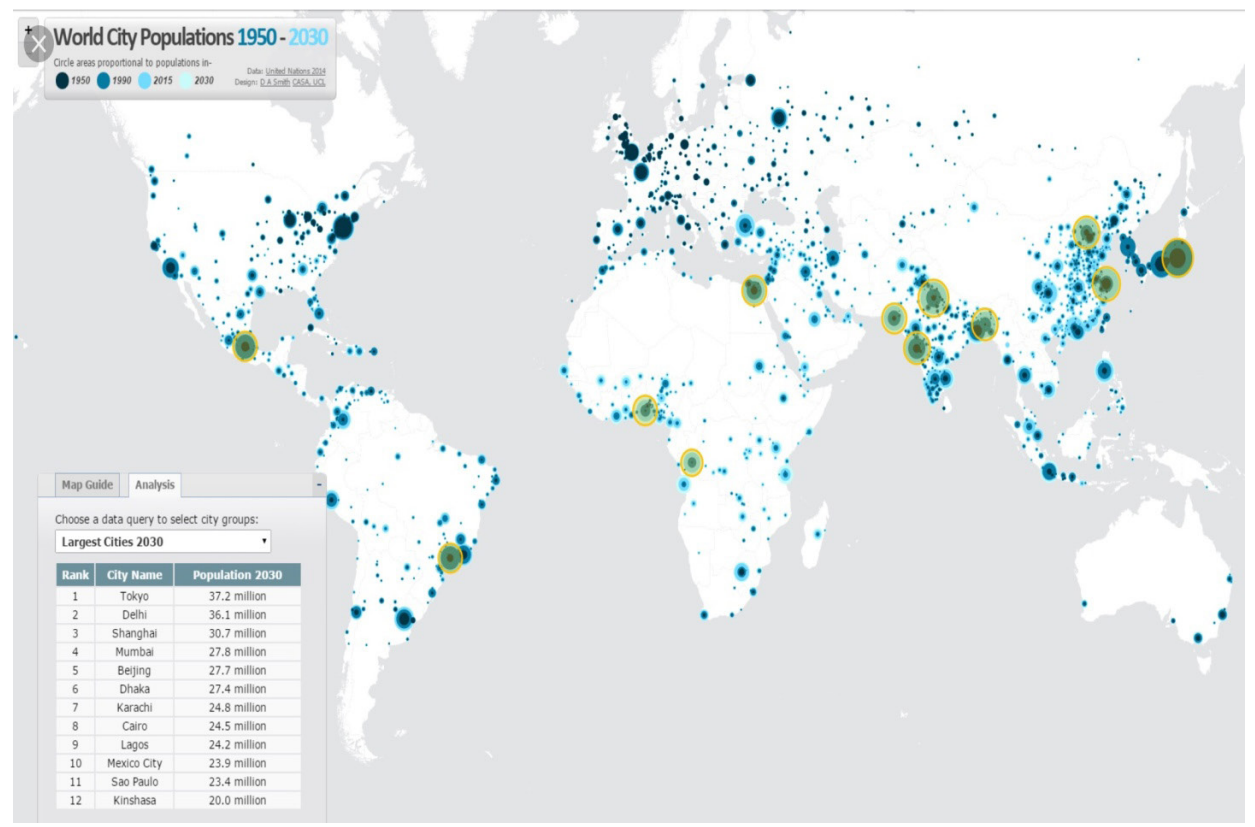

Figure 1. Populations of World Cities 1950-2030

Source: luminocity3d, World City Populations 1950 - 2035 (20 October 2020)

At this point, it would be appropriate to consider the "Demographic Transformation Model" introduced by the American demographic scientist Warren Thomson in 1929 (Kirk, 1996, p.361.).

Within the limits of this proposed model, industrialized countries prioritize the industry rather than the agricultural sector. In these countries, birth rates as well as death rates tended to decrease. While these cities support the economic structure in their regions, they also lead to remarkable transformations and changes in terms of demographics. In this process, economic, cultural, political, social and geographical features play a role in the emergence, proliferation and continuity of global cities (Lee and Reher, 2011, p.2.). Over time, political situations affect the economic futures of countries due to their different structures. This situation can lead to significant changes in the fate of global cities. In addition to migration to global cities or between global cities due to economic reasons, the war conditions experienced by countries also transform the demographic structure of global cities (Moir, Moonen and Clark, 2014, 
p.13.). It should also underlined that the prediction of Frank Notestein has discussed the demographic transition. Regarding his idea, demography would spread to the rest of the World. This type of spreading includes the need for "speeding the processes of social change in directions that yield falling birthrates, which in turn will permit more rapid increases in per capita income" (Notestein, 1953, p.13-31.).

In addition, the migration move from rural areas to urbanized zones has gained a significant density. Some farmers, who use the option of settling in different urban spaces for the better living opportunities and conditions that became an expectation for them, usually choose the areas that develop around the cities as their dwellings when they migrate. In this way, they increase not only the demographic features of the city but also the physical dimensions by settling in these environmental areas. The fact that agriculture has been carried out with modern methods and that the political authorities of the country pursue policies that encourage urbanization are also effective in experiencing this situation. When the effects of these opportunities are combined with the attractive structure of the cities, the intense population flow towards the cities becomes inevitable. For these reasons, it is observed that rural population movements contribute to the natural growth rate of the population of cities (Dumont, 2018, p.19.).

At this point, we have to express that especially after the 1950s, "the level of urbanization and the development of the service industry have a positive correlation; finally, we conclude that the level of urbanization promotes the development of the service industry, in other words, urbanization is the power that promotes the growth of the service industry" (Cheng, 2012, p.13).

In the light of this information, it is seen that cities in other parts of the world have started to grow rapidly since the 1950s. Hosting the world's dense demographic clusters, it is seen that Tokyo (Tokyo's History, Geography and Population) attracted half a million inhabitants every year between 1950 and 1990, with a growth of more than 300,000 in Mexico City (México en Cifras) and Sao Paulo, and around 240,000 in Mumbai (World Population Review Mumbai).

As an exceptional situation, although there are cities that have grown in China and Central Africa, the cities in this region have started to grow rapidly 
since the 1990s with the effect of globalization and the development of the Chinese economy. In 1990, the South Guangdong metropolitan area (World Population Review Guangzhou), which included Shenzhen, Guangzhou and Dongguan, among its cities, had a population of 5.5 million. However, in just 20 years, a population of approximately 32 million has been reached, and an increase of about six times has been observed. As a result of this growth and change process, urbanization has increased worldwide (The Statistics Portal). In this respect, it would be appropriate to consider the table of data on cities with high demographic increase around the world. (see Table 4)

Table 4

Population Change in the World's Ten Largest Cities (1950, 2015, 2030)

\begin{tabular}{|c|c|c|c|c|c|c|}
\hline \multirow{2}{*}{ Nu. } & \multicolumn{2}{|c|}{1950} & \multicolumn{2}{|c|}{2015} & \multicolumn{2}{|c|}{2030} \\
\hline & City & Population & City & Population & City & Population \\
\hline 1 & New York & 12.3 & Tokyo & 38.0 & Tokyo & 37.2 \\
\hline 2 & Tokyo & 11.3 & Delhi & 25.7 & Delhi & 36.1 \\
\hline 3 & London & 8.4 & Shanghai & 23.7 & Shanghai & 30.7 \\
\hline 4 & Osaka & 7.0 & Sao Paulo & 21.1 & Bombay & 27.8 \\
\hline 5 & Paris & 6.3 & Bombay & 21.0 & Beijing & 27.7 \\
\hline 6 & Moscow & 5.4 & Mexico City & 21.0 & Dhakka & 27.4 \\
\hline 7 & Buenos Aires & 5.1 & Beijing & 20.4 & Karachi & 24.8 \\
\hline 8 & Chicago & 5.0 & Osaka & 20.2 & Cairo & 24.5 \\
\hline 9 & Kolkata & 4.5 & Cairo & 18.6 & Lagos & 24.2 \\
\hline 10 & Shanghai & 4.3 & New York & 18.6 & Mexico City & 23.9 \\
\hline
\end{tabular}

Source: WUP2014-Report, (15 October 2020), p.21.

Considering the data on the table, Europe, South and North America seem to be in a leading position among their counterparts in five continents in terms of urbanization and demographic increase. The rise of cities, towns, and other residential areas in terms of urbanization and demographic increase is around $41 \%$ in Africa and $48 \%$ in Asia, and this increase is expected to come to the fore with the effect of increasing birth rates and migration in both regions in the coming decades.

In the 1960s and 1970s, when London, one of the leading cities of Europe, underwent a significant demographic transformation, it entered a period of contraction due to the closure of its big port and the weakening of its industries. However, this contraction was tried to be overcome by the service sector factor. 
Competing with Amsterdam, Frankfurt, Paris and Milan until the 1990s, London appears to have made remarkable progress in the fields of finance and business, media services and arts, advertising, fashion, tourism and information technology. This has put it in a successful position among global cities. In addition, the phenomenon of immigration, which has a role in the formation and development of today's developed metropolitan cities, can be considered in this process.

Accordingly, four main migration waves come to the fore with their multicultural character in this process. The elements of the four main structures of this migration wave; (a) settlers from the former subjects of the former empire in the 1950s and 1970s (India, Pakistan, Jamaica, Cyprus, Nigeria and Hong Kong); (b) from the Balkans, Francophone countries in Africa, Iraq and Afghanistan in the 1990s and early 2000s refugees and asylum seekers from non-imperial areas; (c) illegal immigrants from all over the world, whose numbers have been increasing since the 1990s; and (d) immigrants from former Communist countries after 2004. Moreover, thanks to the migration process, London's metropolitan area has turned into an urban space where more than 300 languages are spoken. In this way, it has become one of the most culturally diverse cities among European cities (Eade, 2010, p.3.). This diversity has also affected the local democracy process of the city, and Sadiq Khan won the elections as the first Muslim mayor in 2016 (Raco and Kesten, 2016, p.19).

Another global city with ethnic diversity stands out as New York. Thanks to the ethnic diversity of the city, it is seen that more than 200 ethnic groups live in New York. In addition to the origins of this population being Portuguese, German, Dutch, Russian, Swedish and Greek, there are the central, southeast and Albany regions of New York, urban areas with predominantly Italian Americans and Irish Americans. There are also many German Americans in the western parts of New York and French Canadians living in the northern tip of New York (New York Population 2019). In addition, the "Statistical Atlas" study handles the ethnic structure in New York's urban space on a district basis. It is seen that this study has been shaped into six categories besides the ethnic based possibility (Race and Ethnicity in New York).

\section{Conclusion}

As a result of the evaluation made in terms of global cities, the demographic transformation and migration-oriented urbanization trend gains momentum 
under the influence of global factors and enter the transformation process. At this point, it is seen that it is important to follow the social, economic, demographic, financial and technological developments by the city administrations as well as the country administrations in order to keep the urban development at the expected levels. At this point, it is understood that global cities have undergone demographic transformation due to migration from south to north. This process brings the natural population growth of countries in continents such as Asia and Africa to a different level.

The demographic structure in cities is also undergoing social transformation. It is seen that this economic contraction and the injustice in the income distribution have a share in this. "The underlying socioeconomic and demographic factors behind the urban transition in developed and less developed countries also differ. The first urbanization wave took place in North America and Europe over two centuries, from 1750 to 1950: an increase from 10 to 52 per cent urban, and from 15 to 423 million urbanites. In the second wave of urbanization, in the less developed regions, the number of urbanites will go from 309 million in 1950 to 3.9 billion in 2030. In those 80 years, these countries will change from 18 per cent to some 56 per cent urban" (UNFPA, 2007, p.7).

As this situation creates prosperous cities, the migration flow towards these cities is accelerating. Due to the selectivity and abstention of international capital, urban administrations hold this power more and open the way for economic developments by increasing the opportunities they offer to global capital.

At the same time, the rapid urbanization experienced in countries that have grown economically in the last 50 years also paves the way for the formation of an economically stable social structure. Furthermore, the data obtained show that developing countries tend to move urbanization and social mobility to higher levels by strengthening and diversifying the development levels and tools they currently have in the next 50 years. Experiencing this process; it raises the possibility of bringing along political, economic, and cultural transformations.

In addition to these, the fact that cities have unresolved problems also puts their position in trouble and causes the residents of these cities to migrate or seek other places. "Migration can be understood as a critical consequence of 
globalization insofar as it concerns not only one nation but the entire international community and as it requires regulation in order to prevent negative economic as well as humanitarian consequences" (Zamor, 2018, p.13). In this process, country and city administrations want to include the qualified population in the demographic structure through migration. This method is considered important by the administrations, in terms of keeping the quality of the city at the highest levels. This causes regular or irregular migration movements, and sometimes brings about unwanted situations in the demography of the cities. "The globalization of migration has had additional effects. Countries become more aware of migration policies that are being established abroad and their governments tend to sometimes mimic them, either for political reasons or because these foreign policies seem attractive to an important sector of their societies" (Zamor, 2018, p.19). From this point of view, to increase the educated population of cities on a global scale to the expected levels, social and economic quality should be preserved. At this point, the importance of making lower and upper scale plans also emerges. In this way, it can be ensured that the qualifications of the cities are preserved, and they are better prepared for possible urban changes expected in the future. To realize this aim, city administrations may focus on attracting investment. "When city management can effectively and efficiently direct investments in physical and social infrastructure, these city assets help to ensure safe, inclusive and diverse cities to live in, and efficient and economically vibrant places to work in. A city rich in such assets and attributes retains and grows its skilled labour, enhances its business attractiveness and expands its economic base for innovation and prosperity" (Tobia (Ed). 2019. p.24.). So, it can be assessed that direct and indirect investment can have an important effect to be focused on urban demographic changes in global cities.

\footnotetext{
Hakem Değerlendirmesi: Dış bağımsız.

Çıkar Çatışması: Yazarlar çıkar çatışması bildirmemiştir.

Finansal Destek: Yazarlar bu çalışma için finansal destek almadığını beyan etmiştir.

Peer-review: Externally peer-reviewed.

Conflict of Interest: The authors have no conflict of interest to declare.

Grant Support: The authors declared that this study has received no financial support.
} 


\section{References}

Andrea Tobia Zevi (Ed). The Century of Global Cities. How Urbanisation Is Changing the World and Shaping our Future Edited by First edition: December 2019

Catherine Dauvergne, Making People Illegal What Globalization Means for Migration and Law, Cambridge University Press, 2008

Cheng, Congjun. “A study of Dynamic Econometric Relationship Between Urbanization and Service Industries Growth in China", Journal of Industrial Engineering and Management JIEM, 2012 - 6(1): 8-15 - Online ISSN: 2013-0953 - Print ISSN: 20138423 http://dx.doi.org/10.3926/jiem.657

DEMOGRAPHIA WORLD URBAN AREAS 13th ANNUAL EDITION April 2017, http://demographia.com/db-worldua.pdf, (22 May 2017)

Dudley Kirk, "Demographic Transition Theory", Population Studies, 50 (1996), 361-387, http://shrinking.ums-riate.fr/Ressources/Chap_01/KIR_96.pdf (22 March 2019)

Emily Moir, Tim Moonen ve Greg Clark, "The future of cities: what is the global agenda?", The Business of Cities, 2014

Gérard-François Dumont," Urban demographic transition"Urban development issues, 2018, https://halshs.archives-ouvertes.fr/halshs-01781454/document (13 March 2020)

Göçİdaresi GenelMüdürlüğ̈̈,http://www.goc.gov.tr/icerik3/gecici-koruma_363_378_4713 ,(20 December 2019).

International Labour Organization, World Employment and Social Outlook: Trends 2017, Geneva, 2017, http://embargo.ilo.org/wcmsp5/groups/public/---dgreports/---dcomm/--publ/documents/publication/wcms_541211.pdf, (15 May 2017)

J. A. Scholte, The Globalization of World Politics, J. Baylis and S. Smith (editörler), The Globalization of World Politics, An Introduction to International Relations, New York: Oxford University Press, 1999.

Jean-Claude Garcia-Zamor, Ethical Dilemmas of Migration, Springer International Publishing, 2018,

John Eade, "Cultural and Ethnic Diversity in Cities: Challenges and Chances", Networking European Citizenship Education, 24-26 June 2010 in Barcelona, Spain

México en Cifras, http://www.beta.inegi.org.mx/app/areasgeograficas/?ag=15, (13 March 2020).

New York Population 2019, http://worldpopulationreview.com/states/new-york-population/, (12 March 2019).

Notestein, Frank W. 1953: Economic Problems of Population Change. In: Proceedings of the Eighth International Conference of Agricultural Economists, New York. 13-31.

Nigel Harris, Urbanization, Economic Development And Policy In Developing Countries, 1990.

UN Member States, http://www.un.org/en/member-states/, (5 May 2020). 
Peter Hall, "Urban Land, Housing, And Transportation: The Global Challenge", Global Urban Development Magazine, Volume 3, Issue 1, November 2007, https://www. globalurban.org/GUDMag07Vol3Iss1/Hall.htm, (20 December 2020).

Pew Research Center, Total Fertility Rate by Religion, Projected From 2010-2050, 2015, http://www.pewforum.org/2015/04/02/main-factors-driving-population-growth/ pf_15-04-02_ch1graphics_fertilityreligion640px/, (15 May 2017).

Pew Research Center, Total Fertility Worldwide, 1950-2050, 2015 http://www.pewforum. org/2015/04/02/main-factors-driving-population-growth/pf_15-04-02_ch1graphics fertilityrateworldwide310px/, (15 May 2017).

Pew Research Center, Average Life Expectancy at Birth, 1950-2050, 2015 http://www. pewforum.org/2015/04/02/main-factors-driving-population-growth/pf_15-04-02 ch1graphics_lifeexpectancy310px/, (17 May 2017).

Race and Ethnicity in New York, https://statisticalatlas.com/place/New-York/New-York/ Race-and-Ethnicity, (12 March 2019).

Raco, M.; Kesten, J. Urban Studies, "The Politicisation of Diversity Planning in a Global City: Lessons from London", ScholarOne Manuscripts, 2016, http://discovery.ucl. ac.uk/1517942/1/PDF_Proof\%20\%283\%29.pdf, (20 November 2020).

Richard Sennet, Ten ve Taş Batı Uygarlığında Beden ve Şehir, Tuncay Birkan (translated) İstanbul: Metis Yayınları, 3rd Edition, 2002.

Robin Hambleton ve Jill Simone Gross, Governing Cities in a Global Era Urban Innovation, Competition, and Democratic Reform, New York: Palgrave Macmillan, 2007.

Ronald D. Lee David S. Reher, Demographic Transition and Its Consequences, New York: Population and Development Review, 2011.

The Statistics Portal, https:/www.statista.com/statistics/270860/urbanization-bycontinent/,(13 March 2020).

The World Bank, http://data.worldbank.org/indicator/SM.POP.REFG (13 March 2017).

Tokyo's History, Geography and Population, http://www.metro.tokyo.jp/ENGLISH/ ABOUT/HISTORY/history03.htm, (13 March 2020).

UN The World's Cities in 2018, Population distribution by size class of settlement* and region, 2018 and 2030, https://www.un.org/en/events/citiesday/assets/pdf/the_worlds cities_in_2018_data_booklet.pdf,(10 September 2020).

United Nations Department of Economic and Social Affairs Population Division, Urban Agglomerations 2014, 2014, http://esa.un.org/unpd/wup/Wallcharts/WUP_2014\%20 Urban\%20Agglomerations\%20Wallchart.pdf (15 September 2020).

United Nations, World Urbanization Prospects The 2014 Revision, New York, 2015, http://esa.un.org/unpd/wup/Publications/Files/WUP2014-Report.pdf, (15 September 2020).

United Nations, 2017 Revision of World Population Prospects, New York, 2017, https:// esa.un.org/unpd/wpp/Publications/Files/WPP2017_KeyFindings.pdf, (15 May 2017). 
UNCHR Statistics The World in Numbers, http://popstats.unhcr.org/en/overview (15 July 2020).

UNFPA, State of World Population 2007 Unleashing the Potential of Urban Growth, 2007, https://www.unfpa.org/sites/default/files/pub-pdf/695_filename_sowp2007_eng.pdf, (03 September 2021), p.7

World Population Review Mumbai,http://worldpopulationreview.com/world-cities/ mumbai-population/, (13 March 2020).

World Population Review Guangzhou, http://worldpopulationreview.com/world-cities/ guangzhou-population/, (13 March 2020). 
